\title{
GAME ONLINE SEBAGAI POLA PERILAKU
}

\section{(Studi Pada Mahasiswa Ilmu Komunikasi Universitas Tadulako)}

\author{
Muhammad Wahid ${ }^{*}$, Ahmad Fauzan ${ }^{1}$ \\ ${ }^{1}$ Jurusan Ilmu Komunikasi Fisip Universitas Tadulako \\ *E-mail: ai.maddukelleng@gmail.com
}

\begin{abstract}
The development of this technology has a big influence on its users, especially with the emergence of online gaming applications in smartphones. Game online is one of the things that are popular among gadget users, this can be seen with the emergence of various types of online games on the smartphone. With the presence of online games and excessive use will cause concern, especially on changes in attitudes and behavior patterns of its users. This research aims to find out and provide an overview of how the behavior patterns of Untad communication science students in doing activities to play Game online. Research methods use qualitative methods. Data collection techniques are in observations and depth interviews. The results showed that the behavior patterns of game online users showed significant changes, behavior patterns formed provided changes that are different from the previous one. Of course, this change in behavior patterns when they have known and started addicted to playing online games so that the changes that appear to change their daily habits.
\end{abstract}

\section{Keywords: Game online; Behavioral Patterns; Students}

\begin{abstract}
ABSTRAK
Perkembangan teknologi tersebut memberikan pengaruh besar kepada para penggunanya terutama dengan munculnya aplikasi game online dalam smartphone. Game online merupakan salah satu hal yang digemari dikalangan para pengguna gadget, hal ini dapat dilihat dengan munculnya berbagai macam jenis game online yang ada dismartphone. Dengan hadirnya game online serta penggunaan yang berlebihan akan menimbulkan kekhawatiran terutama pada perubahan sikap dan pola perilaku para penggunanya. Penelitian ini bertujuan untuk mengetahui dan memberikan gambaran terkait bagaimana pola perilaku mahasiswa ilmu komunikasi Untad dalam melakukan aktivitas bermain Game online. Metode penelitian menggunakan metode kualitatif. Tehnik pengumpulan data ialah observasi dan wawancara mendalam. Hasil penelitian menunjukkan bahwa pola perilaku para pengguna Game online tersebut menunjukkan perubahan-perubahan yang signifikan, Pola perilaku yang terbentuk memberikan perubahan yang berbeda dari yang sebelumnya. tentunya perubahan pola perilaku ini ketika mereka telah mengenal dan mulai kecanduan bermain game online sehingga perubahan yang muncul merubah kebiasaan keseharian mereka.
\end{abstract}

\section{Kata Kunci: Game online; Pola perilaku; Mahasiswa Submisi: 9 Desember 2021}

\section{Pendahuluan}

Internet muncul sebagai sarana komunikasi, kini telah membawa perubahan yang cukup besar bagi kehidupan manusia. Internet sebagai teknologi telah melakukan perubahan yang cukup signifikan, sehingga dimensi ruang dan waktu tidak lagi menjadi hambatan bagi proses komunikasi. Dengan kemunculan internet membuat para pengembang smartphone berlomba lomba untuk menghadirkan berbagai macam fitur 
salah satunya yaitu game online. Fitur ini menarik dan cukup berkembang. Game online adalah game atau permainan digital yang hanya bisa dimainkan ketika perangkat terhubung dengan jaringan internet, memungkinkan penggunanya untuk dapat berhubungan dengan pemainpemain lain yang mengakses game tersebut di waktu yang sama.

Di zaman modern ini, game online sudah tidak asing lagi ditelinga kaum remaja. Dalam 10 tahun terakhir, permainan elektronik atau yang kita sebut dengan game online sudah menjamur dimana-mana, hal ini didukung dengan semakin canggihnya teknologi pada smartphone. Pemain game online biasanya didominasi dari kalangan pelajar, mulai dari SD, SMP, SMA, Mahasiswa bahkan orang dewasa. Para Pelajar yang sering memainkan suatu game online, akan menyebabkan mereka menjadi ketagihan atau kecanduan. Ketagihan memainkan game online akan berdampak buruk, terutama dari segi akademik dan sosialnya. Keseringan memainkan game online hingga berjam-jam akan mengakibatkan penggunanya menjadi ketagihan, dan sering melupakan banyak hal yang lebih penting seperti belajar, beribadah, bahkan kesehatannya sendiri dan kerap membuat pemainnya melupakan kehidupan sosial dalam kehidupan sebenarnya.

Terlebih lagi selama pandemi Covid-19 yang dimana anjuran pemerintah kepada masyarakat untuk selalu mematuhi protokol kesehatan dan juga tidak diperbolehkan tatap muka secara langsung dalam proses belajar mengajar di sekolah maupun di kampus, bekerja dari rumah dan harus lebih sesering mungkin untuk tidak keluar rumah jika tidak ada keperluan yang mendesak.

Oleh sebab itu kegiatan yang dilakukan dirumah selama pandemi Covid-19 bagi pelajar yaitu melaksanakan proses belajar mengajar dari rumah secara online. Selama pandemi Covid-19 ini segala aktivitas masyarakat lebih sering dirumah dibandingkan diluar rumah, sehingga tidak menutup kemungkinan kondisi seperti ini dimanfaatkan para pelajar untuk mengisi waktu bermain game online. Oleh sebab itu hal inilah yang menjadi poin terpenting dalam penelitian ini yaitu di mana peneliti tertarik untuk meneliti fenomena game online sebagai pola perilaku khususnya mahasiswa Ilmu Komunikasi Universitas Tadulako.

\section{Tinjauan Pustaka \\ Perkembangan Game}

Sebenarnya istilah video game sendiri berevolusi dari definisi yang benarbenar teknis hingga konsep umum yang mendefinisikan kelas baru hiburan interaktif. Sebuah produk dikatakan sebagai sebuah produk video game harus memiliki sinyal video yang ditransmisi pada sebuah CRT (cathode ray tube) yang membuat gambar pada layar. Kini, seiring berjalannya waktu, definisi videogame sendiri mencakup teknologi secara lebih luas. Namun, definisi ini secara lebih jelas menjelaskan permainan yang dimainkan pada perangkat keras yang dibuat dengan sirkuit elektronik yang menggabungkan sebuah unsur interaktif.

Perkembangan game dimulai sejak tahun 1950an di Universitas Manchester, Universitas Cambridge, Universitas Pennsylvania, dan Universitas Princeton, disinilah tempat bermulanya video game yang menjadi hiburan kita sehari-hari. Sebelumnya, video game dibagi menjadi tiga kategori: yaitu program pelatihan, dan pengajaran, program penelitian dan program demonstrasi untuk menghibur masyarakat.

Sampai pada tahun 2018 hingga sekarang perkembangan game makin pesat, kita merasakan mudahnya dalam bermain game di smartphone kita masing-masing, dengan resolusi yang luar biasa dan bisa dimainkan bersama dengan orang yang sangat jauh sekalipun (https://sobatgame.com/sejarah-game/). 


\section{Game Online}

Menurut Kamus MacMillan (2009-

2011) Game adalah aktivitas yang dilakukan untuk fun atau menyenangkan yang memiliki aturan sehingga ada yang menang dan ada yang kalah. Sedangkan menurut Eddy Liem, Direktur Indonesia Gamer, internet game adalah sebuah game atau permainan yang dimainkan secara online via internet, bisa menggunakan $\mathrm{PC}$ (personal computer), atai konsul game biasa (PS-2, X-Box, dan sejenisnya) (Kompas cyber media, 2003).

Game online dapat dijumpai dalam kehidupan sehari-hari. Jaman dulu game online hanya bisa dimainkan dengan menggunakan komputer saja. Tetapi saat ini game online bisa diakses menggunakan handphone. Rata-rata saat ini seorang pemain memainkan game online dengan menggunakan handphone dan jaringan internet yang memadai. Biasanya seorang pemain menghilangkan rasa jenuhnya baik itu dari kegiatan sehari-hari (kerja, belajar, dan faktor lainnya) maupun sekedar mengisi waktu luang dengan bermain game online. Tetapi ada juga pemain yang menghabiskan waktunya berjam-jam, bahkan seharian penuh untuk memainkannya dan ada juga menghabiskan waktu jaganya untuk bermain game online (Nisrinafatin: 2020).

\section{Perilaku sosial}

Perilaku dalam bahasa inggris disebut dengan behavior yang berarti kelakuan, tindak tanduk jalan. Perilaku juga terdiri dari dua kata peri dan laku, peri yang berarti sekeliling, dekat, dan melingkupi. Sedangkan laku artinya tingkah laku, perbuatan, tindak tanduk. Perilaku manusia pada hakekatnya adalah suatu aktivitas daripada manusia itu sendiri, perilaku juga adalah apa yang dikerjakan oleh organisme tersebut, baik dapat diamati secara langsung ataupun tidak langsung dan hal ini berarti bahwa perilaku terjadi apabila ada sesuatu yang diperlukan untuk menimbulkan reaksi yakni yang disebut rangsangan, dengan demikian suatu rangsangan tertentu akan menghasilkan reaksi perilaku tertentu. http://digilib.uinsby.ac.id.

Idi Subandy dalam Chaney mengutarakan bahwa gaya hidup kini bukan lagi monopoli satu kelas, tetapi sudah lintas kelas. Mana yang kelas atas, menengah, bawah sudah bercampur baur dan terkadang dipakai berganti-gantian (Chaney, 1996).

Di Indonesia penelitian mengenai perilaku sosial online masih jarang dilakukan bahkan dalm kaitannya penelitian mengenai perilaku sosial online masih jarang dilakukan bahkan dalam kaitannya dengan interaksi sosial online di jejaring komunitas virtual. Mengingat perilaku interaksi sosial online ynag sudah mulai popular di masyarakat Indonesia dan juga terbentuknya komunitas online, maka penelitian mengenai perilaku sosial online terkait jenis aplikasi yang diminati, intensitas, serta aktivitas sosialnya menarik untuk diteliti. Gambaran mengenai pola perilaku sosial online memberikan gambaran bahwa kondisi yang terjadi dalam masyarakat kita, terutama yang terkait dengan pemanfaatan teknologi khususnya game online semakin banyak diminati oleh masyarakat.

\section{Konseptualisasi Penelitian}

Lokasi Penelitian berada di Kota Palu. Penelitian menggunakan metode pendekatan kualitatif. Mengikuti Creswell (2016), penelitian ini berdasarkan pada metodologi yang menyelediki suatu fenomena sosial dan masalah manusia. Teknik pengambilan sampel dilakukan secara purposif yang dipilih berdasarkan tujuan penelitian dengan pertimbangan mendapatkan data langsung dari tangan pertama. Pengumpulan data dilakukan dengan observasi dan wawancara mendalam. Dalam analisis data peneliti menggunakan metode Miles dan Haberman sebagai metode analisis data. 
Hasil Penelitian

Pola Perilaku Gamers dalam Melakukan Aktivitas Game Online

Pada kondisi saat ini ketika aktivitas masyarakat dibatasi termasuk proses belajar mengajar didalamnya, para siswa maupun mahasiswa harus mengawali pembelajaran dari rumah dengan menggunakan media online. Penggunaan teknologi berbasis online saat ini sangat penting untuk memenuhi kebutuhan pembelajaran dari rumah. Perangkat teknologi saat ini juga sangat mendukung dalam pembalajaran online seperti smartphone, komputer ataupun laptop.

Namun dalam perkembangan teknologi saat ini handphone genggam (smartphone), komputer/laptop juga sudah dilengkapi berbagai macam fitur ataupun aplikasi game berbasis online, sehingga masyarakat mudah sekali untuk mengakses atau mendownload aplikasi game online yang telah tersedia diplaystore. Akibatnya dalam kondisi pandemi saat ini ketika proses belajar mengajar lebih sering dilakukan dirumah, banyak mahasiswa justru memanfaatkan kondisi saat ini, Mereka (mahasiswa) yang hidup di era digitalisasi hampir semua melek akan teknologi dan sangat mudah untuk megaplikasikan teknologi dalam hal ini yaitu bermain game online.

Game Online saat ini menjadi sesuatu yang populer dikalangan masyarakat terutama para pelajar dan mahasiswa, maka tak heran kita sering menjumpai mereka asyik bermain game online baik itu di kampus, di café maupun di rumah. Disaat kondisi pandemi justru mereka lebih memilih untuk menghabiskan lebih waktu dirumah untuk sekedar bermain game online. Berdasarkan hasil penelusuran bahwa hal itu dibenarkan oleh mahasiswa yang berada di Prodi Ilmu Komunikasi mereka mengungkapkan bahwa dalam masa pandemi Covid19, mereka lebih banyak menghabiskan waktu dirumah dengan bermain game online, mulai dari pagi hingga larut malam waktu senggang hanya dihabiskan untuk bermain game online. Pola perilaku inilah membuat perubahan aktivitas dalam keseharian mereka.

Berdasarkan hasil temuan dilapangan adapun langkah-langkah yang diperlukan untuk mengatasi permasalahan terkai mengenai bagaimana pola perilaku gamers dalam melakukan aktivitasnya bermain game online. Berikut penyampaian dari salah satu pemain game online. Pernyataan yusran menjelaskan bahwa, mengenal yang namanya game online sejak dari bangku SMP, sebenarnya prosesnya tidak langsung bermain game online tapi diawali mulai dari proses hanya sekedar ikut teman ke warnet lalu hanya menonton orang-orang yang lagi bermain game online dan kemudian ikut mencobanya bersama teman-teman, barulah kemudian mulai tertarik dan ketagihan bermain game online.

Proses yang dilakukan Yusran beda halnya dengan yang dilakukan Geby di awal mengenal yang namanya game online, geby baru setahun yang lalu ini mengenal yang namanya game online berarti bahwa Geby belum terlalu lama mengenal game online awalnya dikarenakan kondisi pandemi dan proses perkuliahan hanya melalui daring ditambah lagi aktivitas keseharian masih dibatasi dan harus bekerja dari rumah, dengan kondisi seperti itu Geby tidak tau mau berbuat apa selama dirumah, akhirnya dengan adanya fasilitas smartphone mulailah mencoba-coba mendownload game online yang lagi trend orang-orang mainkan yaitu game PUBG Mobile. Mulai dari coba-coba main game tersebut akhirnya ketagihan juga sampai sekarang.

Sedangkan Cindy bermain game online tahun 2018, karena dipengaruhi oleh temannya kemudian dia mencoba untuk mendownload game berdasarkan rekomendasi tersebut. Akhirnya atas saran dari temannya tersebut cindy kemudian memainkan beberapa game online yaitu free fire dan mobile legend. Dari situlah kemudian tertarik memainkan game online tersebut sampai sekarang. 
Farhan memulai mengenali yang namanya game online pada saat SMA. Namun disaat itu hanya sebatas bermain di warnet sehingga intensitas bermain game tidak terlalu sering dibandingkan disaat beberapa tahun kemudian ketika mempunyai fasilitas smartphone mulai keseringan bermain game online karena terutama bisa bermian dimanapun dan kapanpun. Apalagi disaat pandemic Covid 19 otomatis segala aktivitas lebih sering menghabiskan waktu dirumah saja daripada diluar.

Tanpa disadari setiap orang dalam bermain game online pasti akan menghabiskan waktu selama berjam-jam. Hal ini dapat kita perhatikan disekeliling kita banyak orang bermain game lupa akan waktu dan mengabaikan aktivitas-aktivitas kesehariannya, terlebih lagi disaat masa pandemi ini masyarakat dianjurkan untuk lebih banyak melakukan aktivitas dirumah masing-masing akibatnya terkadang malas melakukan aktivitas di dalam rumah dan lebih sering meluangkan waktunya dengan hal-hal seperti bermain game online.

Intensitas bermain game online sebenarnya dilihat dari personalnya masing-masing. Dari penjelasan yusran bahwa waktu yang dia habiskan sehari selama bermain game online relatif atau tidak tetap, kadang dua jam kadang juga lebih dari itu. Jadi misalnya sudah selesai bermain game di rumah, tapi ada lagi teman yang ajak nongkrong dan ajak main game berarti waktunya bertambah dalam menghabiskan waktu bermain game online.

Geby sebagai pemain game mengutarakan bahwa, dia sangat suka memainkan game online. Dapat dilihat dari intensitas waktu yang dihabiskan selama bermain game. Hampir seharian full waktunya dihabiskan dalam bermain game online Apalagi sekarang masyarakat dianjurkan untuk lebih banyak dirumah saja dalam beraktivitas dikarenakan pandemi covid 19. Intensitas semacam ini membuat aktivitas yang lainnya dapat terbengkalai, lupa waktu karena keasyikan bermain game.

\section{Analisis dan Interpretasi}

Jika sudah keasyikan bermain game online membuat pemainnya lupa waktu, tanpa disadari waktu yang digunakan selama bermain game begitu banyak dihabiskan, sampai pada akhirnya aktivitas yang lainnya terbengkalai. Seperti yang telah dikemukakan diatas bahwa dengan menghabiskan waktu berjam-jam bermain game online dapat mengabaikan rutinitas yang lainnya, hal ini bisa dikatakan terjadi perubahan pola perilaku yang awalnya normal menjadi tidak normal. Misalnya yang semestinya jam makan siang, jadi terlupakan akhirnya makannya nanti disaat sore hari, yang tadinya tidurnya bisa tepat waktu di malam hari, ini harus begadang sampai larut malam akhirnya bangunnya jadi kesiangan dan bisa saja tidak masuk perkuliahan jika ada perkuliahan terjadwal di pagi hari. Begitu juga dengan tugas perkuliahan bisa saja akan terabaikan jika tidak memperhatikannya dan justru lebih memilih untuk bermain game dari pada mengerjakan tugas dari dosen. ini semua akibat karna keasyikan bermain game online.

Aktivitas bermain game online memberikan kepuasan tersendiri bagi para penikmatnya, sehingga jika ada waktu luang maka di isi dengan bermain game. Walaupun itu menghabiskan waktu berjamjam lamanya tak jadi masalah bagi seorang gamers, asal hasrat kepuasannya dapat tersalurkan melalui game online. terlebih lagi saat ini masa pandemi Covid 19, mau tidak mau masyarakat harus mematuhi anjuran pemerintah untuk sesering mungkin berdiam diri dirumah jika tidak ada urusan yang penting diluar sana. Oleh sebab itu pilihan menghabiskan waktu dirumah dengan bermain game lebih nikmat rasanya daripada menghabiskan waktu diluar dengan resiko terpapar Covid 19.

Selain intensitas penggunaan game online, timbul pertanyaan apa yang menarik dari game online tersebut pasti ada yang membuat mereka sebagai pengguna game ini selalu tertarik dalam memainkan sebuah 
permainan apalagi intensitasnya hampir selalu setiap hari mengisi waktu luang dengan bermain game online sampai menghabiskan waktu berjam-jam. yang menarik dari game online adalah dari grafiknya dan kontrol-kontrol dari game tersebut hal ini yang membuat seorang Yusran sampai tertarik dalam memainkan game online. terlebih juga game perang yang lagi populer saat ini yaitu PUBG Mobile, yang dimana setiap saat meminta untuk update untuk memperbaharui grafik dan item di dalam permainan tersebut, ini salah satu strategi juga dalam menarik perhatian para gamers untuk selalu betah dalam bermain game online tersebut.

Game online memang memberikan sesuatu yang lebih bagi penggunanya, sehingga setiap permainan selalu bersaing dan berlomba-lomba untuk memperbaiki atau memperbaharui kualitas game-nya ini agar dapat menarik bagi setiap pengguna game online diseluruh dunia, hal ini bisa terlihat dari salah satu game online yang sangat populer dan banyak dimainkan oleh para penikmat game online yaitu PUBG Mobile. Dari segi kualitasnya game ini selalu ingin tampil di depan dibandingkan para pesaingnya, dapat dilihat dari setiap saat game ini meminta untuk mengupdate bagi setiap pemain yang mendownload game tersebut.

Pola perilaku gamers ini merupakan aktivitas dari bermain game online yang didukung oleh suatu jaringan komunikasi internet. Dalam perkembangan teknologi berupa smartphone telah merambah keseluruh masyarakat sehingga memberikan suatu pengaruh yang sangat besar bagi masyarakat berupa ketergantungan terhadap alat komunikasi tersebut. Tak hanya orang tua saja namun anak-anak dan remaja semuanya telah menggunakan yang namanya gadget. Hal ini dapat kita amati disekeliling kita bahwa hampir setiap saat masyarakat tak bisa lepas dari yang namanya gadget, ini menimbulkan pertanyaan kenapa keadaan tersebut bisa seperti itu, sebab penggunaan gadget saat ini bukan hanya sekedar digunakan untuk melakukan hubungan komunikasi antara manusia dengan yang lainnya akan tetapi kegunaannya telah bergeser juga menjadi alat untuk bermain game online.

Teknologi saat ini bukan hanya sekedar untuk memudahkan kita dalam berkomunikasi dengan orang lain tetapi juga memberikan pengaruh ketergantungan terhadap diri kita dengan gadget tersebut. Dengan adanya gadget perkembangan dunia game juga tak terbendung, banyaknya aplikasi game online dapat mudah ditemukan pada setiap gadget hal ini memberikan pengaruh pada setiap orang misalnya jika seorang tidak bermain game atau tidak sama permainan game yang dia mainkan maka dia akan merasa ketinggalan zaman.

Tak bisa dipungkiri bahwa memang perkembangan teknologi berupa permainan game online yang tersedia digadget sangat memungkinkan dalam memberikan pengaruhnya terhadap pola perilaku masyarakat. Pola perilaku pada tiap masyarakat tentunya berbeda-beda dari kepercayaan, kebiasaan, serta lingkungan yang berbeda Sebagian besar mempengaruhi perilaku dari setiap individunya dan tentunya akan merubah gaya hidupnya.

Hal ini yang kemudian banyak terjadi dalam masyarakat kita terutama bagi para kalangan remaja, dimana mereka masih duduk di bangku sekolah maupun yang sudah berstatus sebagai mahasiswa. Mereka inilah yang banyak menyumbang dari segi jumlah pemakai aktif pengguna game online. dimana-mana kita sering melihat mereka sedang asyik bermain game baik lagi sendiri maupun nongkrong bersama teman-teman di rumah, di sekolah, di kampus, dan terkadang juga di tempattempat tongkrongan yaitu di café-café. Jika sudah asyik bermain game apalagi bersama dengan teman-teman mereka sudah lupa dengan waktu, aktivitas yang mereka lakukan bersama telah menghabiskan banyak waktu sampai berjam-jam. Padahal disamping itu mungkin masih banyak 
aktivitas yang lebih penting dari apa yang mereka lakukan dalam bermain game online.

Dari awal hasil penelitian tersebut bahwa para informan mengutarakan bagaimana mereka diawal mengenal yang namanya sebuah permainan game online. Yang awalnya hanya sekedar ikut-ikutan bersama teman-teman bermain game pada akhirnya terpengaruh juga untuk memulai mencoba coba permainan game online, ada juga memang sekedar coba-coba untuk mengisi waktu luang namun karena keseringan dalam bermain game online akhirnya tertarik juga sampai ketagihan untuk selalu terus bermain game online. Hal ini kemudian menjadi sebuah aktivitas keseharian mereka terutama dalam mengisi waktu-waktu luang terutama disaat pandemi Covid 19 yang lagi melanda yang membuat segala aktivitas manusia dipaksa untuk bekerja dari rumah. Akibatnya aktivitas lainnya yang mungkin lebih penting dari aktivitas bermain game online dapat terbengkalai yang bisa mengakibatkan dampak buruk bagi para pengguna game online ini. Seperti suka menunda-nunda pekerjaan yang semestinya pekerjaan itu dapat dikerjakan dengan cepat, jika pekerjaan itu memiliki waktu yang cukup lama maka mereka lebih suka menundanya dan lebih memilih bermain game daripada mengerjakan langsung pekerjaan yang prioritas. Bermain game justru mereka anggap lebih penting daripada suatu pekerjaan yang semestinya harus diselesaikan, karena bermain game memberikan kepuasan tersendiri bagi mereka yang suka bermain game dan mereka lebih bersemangat jika diajak bermain game ketimbang mengerjakan suatu pekerjaan. Bermain game online merupakan suatu aktivitas yang tak dapat dihindari, oleh karena itu mereka para gamers ini selalu mengambil kesempatan disela-sela waktu kosong untuk bermain game online hal ini meruupakan sesuatu yang lebih berharga bagi mereka daripada melakukan aktivitas yang lainnya.

Ketika bermain game online para gamers ini juga menghiraukan kondisi tubuh dan kondisi mental mereka dengan cara banyak menghabiskan waktu dengan kurangnya beristirahat dan seringnya begadang sampai lupa waktu, akibatnya bangun jadi kesiangan, tidak sarapan pagi dan jika ada jadwal kuliah pagi terkadang mereka tidak sempat lagi untuk masuk mengikuti perkuliahan, serta juga mengabaikan tugas-tugas perkuliahan jika ada yang diberikan dosen kepada mereka, ini akibat mereka justru lebih banyak memilih untuk bermain game berjam-jam dibandingkan dengan memilih waktu untuk melakukan aktivitas yang lainnya, sehingga akibatnya mereka mengalami kesulitan dalam mengatur waktu dan kesulitan dalam beraktivitas, Hal inilah yang dapat menyebabkan mereka selalu suka menunda-nunda pekerjaan yang semestinya pekerjaan itu harus segera diselesaikan.

Bagi mereka bermain game online merupakan sesuatu yang dapat memberikan kepuasan tertentu yang justru tidak bisa didapatkan diberbagai aktivitas lainnya. Dalam melakukan aktivitas bermain game online setiap saat dan setiap waktu tentunya dapat memberikan suatu kepuasan bagi yang memainkannya sehingga aktivitas ini sama halnya seperti kebutuhan utama yang harus dipenuhi dalam kehidupan seharihari, jika tidak terpenuhi maka dapat mengakibatkan hal yang tidak baik bagi diri seorang gamers. Dalam berinteraksi mereka terkadang membatasi ruang lingkup interaksi mereka, jika sudah keasyikan bermain game online mereka justru lebih sering berinteraksi dengan teman yang ada di dunia virtual game daripada teman yang berada di dunia nyata. Begitupun juga ketika berada dirumah mereka jarang berinteraksi dengan keluarga, padahal keluarga adalah orang yang paling dekat dengan kita. ini yang bisa dapat ditelisik melalui dari penelitian ini dengan melihat beberapa informan yang aktif dalam menggunakan game online, data yang terkumpul dapat berupa hasil wawancara yang kemudian dianalisis dalam pembahasan ini. 


\section{Simpulan}

Sampai pada kesimpulan bahwa peneliti ingin menyimpulkan dari pembahasan masalah pola perilaku sosial mahasiswa prodi Ilmu Komunikasi Untad dalam aktivitasnya selama bermain game online. Jika kita menelisik pada perkembangan teknologi saat ini, dimana gadget yang duhulunya hanya sekedar mempermudah manusia dalam berkomunikasi dengan yang lainnya, maka di era sekarang dimana teknologi mengalami kemajuan yang sangat pesat membuat gadget tak hanya sebagai alat komunikasi tetapi dipadukan dengan permainan game yang telah tersedia digadget.

Sangat mudahnya mengakses permainan game di gadget maka dengan itu pula para penggunanya juga dengan mudah bermain game dimana saja dan kapan saja tentunya didukung dengan jaringan internet. Disaat itu pula waktu yang kita punya dihabiskan untuk bermain game online dan dilakukan secara terus menerus dan berulang-ulang. Terlebih disaat pandemik saat ini yang dimana kebanyakan mahasiswa lebih sering belajar dari rumah dan menghabiskan waktunya hanya untuk bermain game online, Maka pola perilaku dalam bermain game online tersebut akan menjadi gaya hidup tanpa kita sadari.

Pola perilaku yang terbentuk memberikan perubahan yang berbeda dari yang sebelumnya. Hal ini kemudian dirasakan oleh mereka, dikatakan bahwa pola perilaku yang sangat mendasar dalam perubahan keseharian mereka selama bermain game online adalah jam tidur yang sudah tidak normal, kemudian makan yang sudah tidak teratur, interaksi dengan teman teman kampus ataupun keluarga yang ada dirumah mulai berkurang. Belajar sudah tidak maksimal sehingga mengakibatkan kurang diperhatikannya jam perkuliahan, ini juga diakibatkan karena terlalu sering bermain game online sampai begadang lupa waktu untuk beristirahat.

\section{Referensi}

Abrar, Ana Nadhya.2003.Teknologi Komunikasi Perspektif Ilmu Komunikasi.Yogyakarta, LESFI.

Alyusi, Shiefti Dyah. 2016. Media Sosial: Interaksi, Identitas dan Modal Sosial, Jakarta, Kencana

Chaney, David. 1996. LifeStyle: Sebuah Pengantar Komprehensif, Yogyakarta, Jalasutra

Creswell,J.W.(2016) Research Design, Pendekatan Kualitatif, Kuantitatif dan Mixed. Yogyakarta. Pustaka Pelajar. http://digilib.uinsby.ac.id http://repositori.uin-alauddin.ac.id/11338/1/ https://sobatgame.com/sejarah-game/ https://ummaspul.e-

journal.id/JENFOL/article/download/ 427/244/

https://www.kompas.com/sains/read/2020/0 3/26/123700223/teknologi-yangmengerti-kita- di-tengah-wabahvirus-corona? page $=$ all.

https://www.kompas.com/skola/read/2020/ 10/26/152337669/sejarah-

perkembangan- teknologi-informasidan-komunikasi?page $=$ all

Huberman, M. B. M. dan A.M. (2014). Analisis Data Kualitatif, Buku Sumber Tentang Metode-Metode Baru. Jakarta: UI-Press. https://doi.org/Http://uipress.ui.ac.id.

Janti, Nur, dkk.2014. Online, Geliat Manusia Dalam Semesta Maya.Yogyakarta.Ekspresi Buku

Miles, Matthew B, dan Huberman, A. Michael. 1992. Qualitative Data Analysis. (Terjemahan: Tjetjep Rohendi dengan judul: Analisis Data Kualitatif), UI-Press: Jakarta

Muttaqin, M.Rizal. 2019. Sejarah Singkat Perkembangan Game. https://informatika.unida.gontor.ac.id/ 2019/04/23/sejarah-singkatperkembangan- game/

Nisrinafatin, 2020. Pengaruh game online Terhadap Motivasi Belajar Siswa.

Noegroho, Agung. 2010. Teknologi Komunikasi. Yogyakarta, Graha Ilmu. Nasution, S. 1992. Metode Penelitian 
Naturalistik Kualitatif. Bandung, Tarsito.

Salim, Agung. 2016. Pengaruh GameOnline Terhadap perilaku Belajar Mahasiswa Jurusan Pendidikan Agama Islam Fakultas Tarbiyah dan Keguruan UIN Alauddin Makassar. 